\title{
DETERMINATION OF FERMENTATIVE YEAST ACTIVITY BY ETHANOL BY REFRACTOMETRIC METHOD
}

\author{
V. Ridkous
}

National University of Food Technologies

\begin{tabular}{l}
$\quad$ Key words: \\
Fermentative yeast \\
activity \\
Ethanol \\
Real extract \\
Index of light refraction \\
Refractometry \\
\hline
\end{tabular}

Article history:

Received 06.07.2018

Received in revised form

18.07.2018

Accepted 20.08.2018

Corresponding author:

V. Ridkous

E-mail:

Ridkous@ukr.net

\begin{abstract}
In order to determine fermentative yeast activity by accumulated ethanol and unfermented real extract the efficiency and simplicity of measuring are the urgent tasks. The paper represents trials of determining of ethanol content and real extract by index of light refraction of fermented wort. Fermentation by chosen yeast of model wort - sucrose solution was carried out. In given starting concentration of sugar in wort (during fermentation) relation between content of accumulated ethanol (that is product of fermentation) and real extract (that is remained unfermented) on index of light refraction is identical described analytically. Previously, in given starting concentration of sugar in wort the relations of index of light refraction from content of accumulated ethanol and unfermented real extract (sucrose) in fermented wort have been analytically calculated for each concrete trial by means of refractometric tables for sucrose and ethanol and meanings of alcohol yield. The indexes of light refraction of fermented wort were measured by refractometric method. Ethanol and real extract content have been determined by previously calculated relations.

Determined indexes of ethanol and real extract were compared to the relevant indexes that were determined by standard methods. The possibility of using of analytical calculations and refractometric measuring for express-method of detecting of ethanol and real extract content in fermented wort during determination of yeast fermentative activity has been proven based on performed research. Average inaccuracies in determination of ethanol content is $0.14 \mathrm{vol} . \%$, and in determination of real extract content is $0.20 \%$.
\end{abstract}

DOI: $10.24263 / 2225-2924-2018-24-4-20$

\section{ВИЗНАЧЕННЯ БРОДИЛЬНОЇ АКТИВНОСТІ ДРІЖДЖІВ ЗА СПИРТОМ РЕФРАКТОМЕТРИЧНИМ МЕТОДОМ}

\author{
В.В. Рідкоус
}

Національний університет харчових тхенологій

Попередньо для кожного конкретного випадку, при заданій початковій концентрації иукрози в суслі, за рефрактометричними таблицями для цукрози 
й етилового спирту, та значеннями виходу етилового спирту з иукрози, аналітично розраховано залежності значення показника коефіиієнта заломлення світла від вмісту накопиченого етилового спирту і незбродженого дійсного екстракту (иукрози) в зброджуваному суслі. Рефрактометричним методом заміряно показники коефімієнта заломлення світла зброджуваного сусла $i$ за попередньо розрахованими залежностями визначено в ньому вміст етилового спирту $і$ дійсного екстракту.

Визначені показники етилового спирту $і$ дійсного екстракту порівняно $з$ відповідними показниками, визначеними стандартними методами. На підставі проведених експериментів доведено можливість використання аналітичних розрахунків і рефрактометричних вимірювань для експрес-методу знаходження вмісту етилового спирту $i$ дійсного екстракту у зброджуваному суслі при визначенні бродильної активності дріжджів. Середні похибки при визначенні вмісту етилового спирту становлять 0,14\%об., а при визначенні вмісту дійсного екстракту - 0,20\%.

Ключові слова: бродильна активність дріжджів, етиловий спирт, дійсний екстракт, показник коефіцієнта заломлення світла, рефрактометричний метод.

Постановка проблеми. Дріжджі $є$ основною сировиною в технології бродильних, хлібопекарних і кондитерських виробництв. Головним показником якості дріжджів $€$ їхня бродильна активність.

Бродильна активність дріжджів - це спроможність одиниці маси дріжджів за одиницю часу при заданій температурі і $\mathrm{pH}$ зброджувати певну масу цукрів до етилового спирту і вуглекислого газу. Різні цукри зброджуються з різною швидкістю. Перш за все зброджуються глюкоза і фруктоза. Повільніше зброджуються мальтоза і цукроза, які попередньо за допомогою ферментів дріжджів гідролізуються до простих цукрів. Залежно від цукру, який у лабораторних умовах використовується в зброджуваному суслі, розрізняють зимазну і мальтазну активність дріжджів.

Зимазна активність дріжджів - це швидкість зброджування дріжджами глюкози чи цукрози.

Мальтазна активність дріжджів - це швидкість зброджування дріжджами мальтози.

Бродильну активність дріжджів визначають такими методами:

- за зменшенням маси проби після бродіння за рахунок втрати вуглекислого газу, що є критерієм сили бродіння;

- за об'ємом виділеного вуглекислого газу;

- за кількістю накопиченого етилового спирту;

- за кількістю незбродженого екстракту (цукру), що залишився.

Широко розповсюджене визначення бродильної активності дріжджів за об'ємом виділеного вуглекислого газу здійснюється на різноманітних конструкціях лабораторних установок - зимографах. Але всі вони мають головний недолік - визначення відбувається на стадії пристосування дріжджів (лаг-фаза) до середовища бродіння, а результати мають більше порівняльний характер, ніж відображають реальну картину динаміки бродіння. I хоча всі відомі способи 
визначення бродильної активності не можуть дати повної і точної уяви про інтенсивність процесу бродіння, який відбувається в виробничих умовах, заміри показників накопиченого етилового спирту і незбродженого дійсного екстракту при зброджуванні заданого сусла в лабораторних умовах дають більш-менш повну уяву про динаміку бродіння. Але визначення вище наведених показників стандартними методами для відстежування динаміки бродіння громіздке, трудомістке і мало придатне навіть в лабораторних умовах.

Для оперативного відстежування динаміки бродіння в лабораторних умовах запропоновано скористатися аналітичним і рефрактометричним методами визначення етилового спирту й дійсного екстракту.

Аналіз останніх досліджень і публікацій. Рефрактометричний аналіз суміші із трьох компонентів грунтується на правилі адитивності показників заломлення:

$$
n=n_{0}+n_{1}+n_{2} \text {. }
$$

Коли одним із компонентів суміші $\epsilon$ вода (для дистильованої води $\left.n_{D}^{20}=1,33299\right)$, то, визначивши концентрацію другої з речовин іншим методом, можна рефрактометрично визначити концентрацію третьої речовини.

Але рефрактометричний аналіз потрійних систем, які складаються із розчинника і двох розчинених речовин, можливий і без попереднього кількісного визначення однієї з них. Для вирішення цього завдання з двома невідомими необхідне визначення другого, крім показника заломлення, параметра, що характеризує склад системи. Доволі часто використовується рефрактоденсиметричний метод, що полягає у вимірюванні показника заломлення $\mathrm{i}$ густини розчину. Сутність цього методу: одному показнику заломлення може відповідати нескінченно велика кількість співвідношень двох розчинених речовин. Те ж саме можна сказати і про густину. Але одному показнику заломлення і одній густині (для того ж розчину) відповідає тільки одна концентрація кожного $з$ двох розчинених речовин.

Визначення складу суміші рефракто-денсиметричним методом, зазвичай, відбувається графічно. Для цього готується велика кількість потрійних сумішей точно відомого складу і вимірюються їхні показники заломлення $\mathrm{i}$ густини. Потім будується трикутна діаграма 3 сіткою ізорефракт та ізоденс (лінії однакових показників заломлення і лінії однакової густини). Для визначення складу досліджуваного розчину знаходять точку перетину ізорефракти та ізоденси, що відповідає показнику заломлення і густині суміші. Рефрактоденсиметричний аналіз був запропонований ще в 1843 р. для визначення вмісту спирту й екстрактивних речовин у пиві $[1 ; 2]$.

Головними недоліками цього методу є громіздкість та велика затрата часу на розробку діаграми (підготовчі роботи), невисока точність результатів аналізу, незручність користування діаграмою та необхідність мати порівняно велику кількість аналізованої суміші для точного визначення густини.

Для рефракто-денсиметричного аналізу потрійної системи цукроза-етиловий спирт-вода можна побудувати діаграму в прямокутній системі координат, що підвищує зручність користування діаграмою, але не усуває вищенаведених недоліків. 
Існує спосіб визначення спирту й екстракту у винах методом двох параметрів [3]. Заміри показника заломлення світла і густини вина дають змогу вирахувати об'ємну частку етилового спирту і масову частку загального екстракту. При розрахунку підставляються значення показника заломлення i густини за цукровою шкалою.

В основі методу лежить той факт, що етиловий спирт збільшує показник заломлення світла і зменшує густину вина, тому при збільшенні об'ємної частки спирту збільшується різниця між показами рефрактометра й ареометра. Цукри та інші розчинні речовини збільшують і показник заломлення світла, і густину вина, тому при збільшенні їх масової частки збільшується сума показників рефрактометра й ареометра. 3 цього випливає, що за різницею показань приладів можна визначити об'ємну часку спирту, а за їх сумою - масову частку екстракту.

Недоліком цього методу є необхідність мати порівняно велику кількість аналізованої суміші для точного визначення густини.

Повідомляється про вимірювання в технологічних потоках і стоках в цукрово-етанольній промисловості з використанням оптоволоконного датчика, що функціонує на принципі відбивання Френеля. Калібровку приладу здійснювали бінарними розчинами цукроза-вода і етанол-вода. Потім аналізували побічні продукти різних стадій виробництва. Абсолютна похибка не перевищувала $\leq 5 \%$ i $\leq 5 \%$ об., відповідно, для цукрози і етанолу. Оптоволоконний датчик забезпечував надійні результати навіть для зразків зі складними композиціями порівняно з чистими розчинами цукрози й етанолу, що робить перспективним його застосування на деяких стадіях виробництва [4].

Для всіх продуктів бродіння, таких як модельні суміші (для визначення бродильної активності дріжджів за динамікою бродіння), квас, пиво, вино, чи спиртова бражка, попередником є сусло. Сусло складається з води і розчинних сухих речовин, які називаються екстрактом. Менша частина екстракту дріжджами не зброджується, залишаючись у суслі в незмінному вигляді. Більша частина екстракту, що являє собою прості цукри (глюкозу, фруктозу), дисахариди (мальтозу, цукрозу), або трисахарид мальтотріозу, зброджується дріжджами до етилового спирту і вуглекислого газу. Вуглекислий газ виділяється з сусла в атмосферу, а етиловий спирт еквівалентно заміщає в суслі зброджені цукри. Тому залежність між вмістом накопиченого етилового спирту (що утворився зі збродженого екстракту) і дійсного екстракту (що залишився незбродженим), від показника коефіцієнта заломлення світла зброджуваного сусла, однозначно описується аналітично.

Дуже часто в лабораторній практиці є необхідність оперативного відстежування динаміки бродіння, наприклад, для визначення бродильної активності дріжджів, яку можна реалізувати вищенаведеним методом.

Мета дослідження: визначення вмісту етилового спирту i дійсного екстракту за показником коефіцієнта заломлення світла зброджуваного сусла. Цей параметр вимірюється з високою точністю рефрактометричним методом і має малий час вимірювання, що дає можливість проводити експрес-аналізи.

Матеріали і методи. Для досліджень використовували цукор білий за ДСТУ 4623, воду дистильовану за ГОСТ 6709, дріжджі хлібопекарські пресовані за ДСТУ 4812 чи дріжджі сухі інстантні (високоактивні). 
Для експериментальної оцінки методу готували сусло 3 10\% концентрацією цукрози. До сусла додавали дріжджі в кількості $1,0 \%$ по сухих речовинах (СР). Сусло зброджували періодичним способом при температурі $30^{\circ} \mathrm{C}$. Визначення етилового спирту та дійсного екстракту проводили як за нижчеописаною методикою, так і по ДСТУ 7104.

Результати і обговорення. Теоретичний вихід етилового спирту зі 100 кг дисахаридів (цукрози) становить 53,835 кг. При бродінні сусла цукор також витрачається на розмноження і ріст дріжджів (до 1,5\%), утворення гліцерину

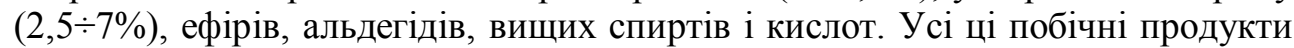
спиртового бродіння при необхідності можливо буде врахувати за допомогою поправочного коефіцієнта, який буде залежати від накопиченого етилового спирту (тривалості бродіння).

Попередньо, для кожного конкретного випадку, при заданій початковій концентрації цукрози в суслі, за рефрактометричними таблицями для цукрози й етилового спирту (методом інтерполяції та розрахункових формул), i виходу етилового спирту з цукрози - 0,53835 кг/кг, в електронних таблицях Excel розраховували аналітично та зображали графічно залежність показника коефіцієнта заломлення світла від вмісту незбродженої цукрози і накопиченого етилового спирту в зброджуваному суслі.

Таблицю 1 заповнювали таким чином: у стовпчику 1 записували концентрації цукрози (\%) з певним кроком від 0 до заданої (в даному випадку $10 \%$ ). У стовпчику 2 записували взяті 3 рефрактометричної таблиці для цукрози відповідні показники коефіцієнтів заломлення світла. В стовпчику 3 вираховували концентрацію етилового спирту (\%), що утворився від зброджування цукрози: $(10,0-$ «значення стовпчика $1 ») \cdot 0,53835$. У стовпчику 4 вели перерахунок концентрації етилового спирту (з \% у \%об.) : «значення стовпчика $3 » \cdot d_{4}^{20}$ [для даної масової концентрації етилового спирту] : 0,78927 [відносна густина $100 \%$ етилового спирту]. В стовпчику 5 записували взяті 3 рефрактометричної таблиці для етилового спирту відповідні показники коефіціснтів заломлення світла. В стовпчику 6 вираховували загальний показник заломлення світла суміші: («значення стовпчика 2»+ «значення стовпчика 5»-1,332986. Потім перезаписували значення стовпчиків 6,1 і 4 (лівої частини таблиці) у стовпчики 7, 8 і 9 (у правій частині таблиці).

Для проведення досліджень використовували рефрактометр Аббе з похибкою вимірювань $n \pm 0,0002$.

У подальшому рефрактометром заміряли показник коефіцієнта заломлення світла фільтрату зброджуваного сусла і за стовпчиками 7, 8, i 9 методом інтерполяцій визначали інші показники (табл. 1). Excel

Таблиця 1. Розрахунки параметрів зброджуваного сусла в електронних таблицях

\begin{tabular}{|c|c|c|c|c|c|c|c|c|}
\hline \multicolumn{2}{|c|}{ Цукроза } & \multicolumn{4}{|c|}{ Етанол Суміш } & Суміш \\
$y_{0}^{20}$ & $n_{D}^{20}$ & $\%$ & $\%$ об. & $n_{D}^{20}$ & $\begin{array}{c}\text { Цукроза, } \\
\%\end{array}$ & $\begin{array}{c}\text { Етанол, } \\
\% \text { об. }\end{array}$ \\
\hline 1 & 2 & 3 & 4 & 5 & 6 & 7 & 8 & 9 \\
\hline 0,0 & 1,332986 & 5,3835 & 6,744065 & 1,336257 & 1,336257 & 1,3363 & 0,00 & 6,74 \\
\hline
\end{tabular}


Продовження табл. 1

\begin{tabular}{|c|c|c|c|c|c|c|c|c|}
\hline 1 & 2 & 3 & 4 & 5 & 6 & 7 & 8 & 9 \\
\hline 1,0 & 1,334420 & 4,84515 & 6,075048 & 1,335909 & 1,337343 & 1,3373 & 1,00 & 6,08 \\
\hline 2,0 & 1,335864 & 4,3068 & 5,4046 & 1,335520 & 1,338398 & 1,3384 & 2,00 & 5,40 \\
\hline 3,0 & 1,337320 & 3,76845 & 4,7334 & 1,335289 & 1,339623 & 1,3396 & 3,00 & 4,73 \\
\hline 4,0 & 1,338786 & 3,2301 & 4,061525 & 1,334960 & 1,340760 & 1,3408 & 4,00 & 4,06 \\
\hline 5,0 & 1,340264 & 2,69175 & 3,38969 & 1,334611 & 1,341889 & 1,3419 & 5,00 & 3,39 \\
\hline 6,0 & 1,341753 & 2,1534 & 2,71397 & 1,334314 & 1,343081 & 1,3431 & 6,00 & 2,71 \\
\hline 7,0 & 1,343253 & 1,61505 & 2,036462 & 1,334016 & 1,344283 & 1,3443 & 7,00 & 2,04 \\
\hline 8,0 & 1,344765 & 1,0767 & 1,358686 & 1,333647 & 1,345426 & 1,3454 & 8,00 & 1,36 \\
\hline 9,0 & 1,346289 & 0,53835 & 0,679869 & 1,333296 & 1,346599 & 1,3466 & 9,00 & 0,68 \\
\hline 10,0 & 1,347824 & 0 & 0 & 1,332986 & 1,347824 & 1,3478 & 10,00 & 0,00 \\
\hline
\end{tabular}

Середні похибки при визначенні вмісту етилового спирту становлять $0,14 \%$ об., а при визначенні вмісту дійсного екстракту - $0,20 \%$. Ці значення похибок можна одержати на основі формул похибок і результатів експериментальної перевірки рефрактометричного методу.

У табл. 2 представлені результати дослідження зброджуваного сусла рефрактометричним методом і стандартними методами визначення вмісту етилового спирту і дійсного екстракту [5].

Таблиия 2. Вміст дійсного екстракту і етилового спирту при зброджуванні чисто цукрозовмісного сусла $з$ початковою концентрацією $10 \%$

\begin{tabular}{|c|c|c|c|c|}
\hline \multirow[b]{2}{*}{$\begin{array}{c}\text { Тривалість } \\
\text { бродіння, год }\end{array}$} & \multicolumn{2}{|c|}{ Етиловий спирт, \%об. } & \multicolumn{2}{|c|}{ Дійсний екстракт, \% } \\
\hline & $\begin{array}{c}\text { Рефракто- } \\
\text { метричним } \\
\text { методом }\end{array}$ & $\begin{array}{c}\text { Дистиляційним } \\
\text { методом }\end{array}$ & $\begin{array}{c}\text { Рефракто- } \\
\text { метричним } \\
\text { методом }\end{array}$ & $\begin{array}{c}\text { Гравіметричним } \\
\text { методом }\end{array}$ \\
\hline 1 & 0,3 & - & 9,5 & - \\
\hline 2 & 0,8 & - & 8,8 & - \\
\hline 3 & 1,3 & - & 8,1 & - \\
\hline 4 & 2,0 & 1,98 & 7,1 & 7,09 \\
\hline 5 & 2,5 & - & 6,3 & - \\
\hline 6 & 3,1 & - & 5,4 & - \\
\hline 7 & 3,7 & - & 4,4 & - \\
\hline 8 & 4,3 & 4,34 & 3,7 & 3,65 \\
\hline 9 & 4,8 & - & 2,9 & - \\
\hline 10 & 5,1 & - & 2,4 & - \\
\hline 11 & 5,4 & - & 2,0 & - \\
\hline 12 & 5,6 & 5,65 & 1,7 & 1,64 \\
\hline
\end{tabular}

\section{Висновки}

На підставі проведених експериментів доведена можливість використання аналітичних розрахунків і рефрактометричних вимірювань для експресметоду знаходження вмісту етилового спирту і дійсного екстракту в зброджуваному суслі при визначенні бродильної активності дріжджів. Результати, одержані рефрактометричним методом, в межах точності досліду узгоджуються із результатами, одержаними стандартними методами. Малий час вимірювань, доступна апаратура і нескладна методика вимірювань дають можливість широко використовувати метод у лабораторній практиці. 


\section{Лiтература}

1. Фармацевтическая химия. 1. Теоретический материал по темам. / Под ред. акад. РАМН, проф. А.П. Арзамасцева. - Москва, 2004. — 662 с. [Електронний ресурс]. Режим доступу: http://pharmchem.nuph.edu.ua/assets/templates/farm/files/\%D0\%A3\%D1\%$87 \%$ D0 $\%$ B5\%D0\%B1\%D0\%BD $\%$ D1\%8B $\%$ D0\%B5\%20\%D0\%BC $\%$ D0\%B0\%D1\%82\%D0\% B5\%D1\%80\%D0\%B8\%D0\%B0\%D0\%BB\%D1\%8B/farmkhimia_kniga.pdf (дата звернення: 22.01.2018).

2. Илларионова E.A. Метод рефрактометрии. Применение в фармацевтическом анализе : учебное пособие / Е.А. Илларионова, И.П. Сыроватский ; ФГБОУ ВО ИГМУ Минздрава России, Кафедра фармацевтической и токсикологической химии. Иркутск : ИГМУ, 2017. 51 с. [Електронний ресурс]. - Режим доступу: http://docplayer.ru/59480339-Metod-refraktometrii-primenenie-v-farmacevticheskom-analize.html (дата звернення: 22.01.2018).

3. Визначення спирту і екстракту у винах методом двох параметрів / I.I. Побережець, B.I. Побережець, I.I. Побережець // Збірник наукових праць Уманського національного університету садівництва. — 2014. — Вип. 86(1). - С. 122 - 128. [Електронний ресурс]. Режим доступу: http://www.journal.udau.edu.ua/assets/files/86/agro/ukr/20.pdf (дата звернення: 22.01.2018).

4. Measurement of sucrose and ethanol concentrations in process streams and effluents of sugarcane bioethanol industry by optical fiber sensor / Eric Fujiwara, Eduardo Ono, Tarcio P. Manfrim, Juliana S. Santos, Carlos K. Suzuki [Електронний ресурс]. - Режим доступу: https://www.spiedigitallibrary.org/conference-proceedings-of-spie/7753/1/Measurement-of-sucrose-and-ethanol-concentrations-in-process-streams-and/10.1117/12.885096.short?SSO=1\#ArticleLink (дата звернення: 22.01.2018).

5. ДСТУ 7104:2009 Пиво. Методи визначання спирту, дійсного екстракту та розраховування сухих речовин у початковому суслі [Електронний ресурс]. — Режим доступу: http://document.ua/pivo_-metodi-viznachannja-spirtu-diisnogo-ekstraktu-ta-rozra-std3594.html (дата звернення: 22.01.2018). 